\title{
Sudden Death in Chagas' Disease
}

\author{
A nis Rassi Jr, Sérgio Gabriel Rassi, A nis Rassi \\ Goiânia, GO - Brazil
}

Sudden death is one of the most expressive phenomena of the natural history of Chagas' disease, affecting individuals in the most productive phases of their lives. In general, considering all evolutionary stages of the disease, we can say that sudden death is the major cause of death in this disease. It is worth noting that in 1912 the Brazilian Carlos Ribeiro Justiniano Chagas ${ }^{1}$, the genial discoverer of the disease, reported the following: "We have numerous clinical observations of the cardiac form and a large number of autopsies that serve as the basis for factual interpretation. In the regions where the disease is common, the number of adult individuals with profound cardiac disorders is impressive... The immediate consequence of this fact is the great number of rapid deaths caused by the disease, and is really impressive in the statistics of lethality the great number of people dying suddenly due to cardiac syncope." Later, the author added ${ }^{2}$ that a large number of families were shocked by the sudden death of one or several members, who died young and in apparent good health, in a phase of tolerance of the cardiac affection.

Chagas' disease is a major epidemiologic problem not just in Brazil. At this time it is considered the fourth disease of major social impact in Latin America, where it affects 16 to 18 million individuals. At least 80 million more individuals (approximately one quarter of the entire Latin American population) are at risk for acquiring the infection ${ }^{3}$. Despite all of this, systematized studies aiming to determine the real prevalence of sudden death in the chagasic population, its mechanisms, risk factors, and prevention are scarce. Therefore, an updated review about this complex, challenging, and important problem of public health is necessary.

\section{Causes of death in Chagas' disease and frequency of sudden death}

Death in Chagas' disease may result from cardiovas-

Hospital São Salvador - Goiânia

Mailing address: Anis Rassi Jr - Hospital São Salvador - Av. A, 333 -

Setor Oeste - 74110-020 - Goiânia, GO, Brazil

English version by Stela Maris C. Gandour cular causes, which are the most common, and noncardiovascular causes. The determining mechanism of cardiovascular death may be either an arrhythmic event, often ventricular fibrillation and, less commonly, ventricular asystole, or a nonarrhythmic event such as pump failure (congestive heart failure), or even embolic phenomena (cerebral, pulmonary, mesenteric, etc). Noncardiovascular causes comprise complications of megaesophagus and megacolon.

In regard to the frequency of sudden death in Chagas' disease, data are conflicting, because they are under the influence of several factors, such as the concept of sudden death adopted, the population sample considered (field, office, or hospital) and its demographic characteristics (age, sex, race), the evolutionary stage of the disease, the degree of ventricular dysfunction of the patients in the studies, the type of treatment administered, and obviously, the time interval of patient's follow-up.

A satisfactory and consensual definition of sudden death does not exist. For some authors ${ }^{4-6}$, sudden death is the one that occurs naturally within seconds, minutes, or hours after onset of signs or symptoms, or both, seen by others and in an out of hospital environment, affecting apparently healthy individuals or those who at least seem so to people around them. For others ${ }^{7,8}$, death occurring suddenly in patients with previous clinical manifestations of cardiovascular disease or any other illness should also be considered sudden death, and one classical example is the sudden death occurring after acute myocardial infarction ${ }^{9}$.

Aiming to differentiate and better characterize these two situations, some authors when referring to sudden death in ischemic heart disease ${ }^{10}$, and mainly in Chagas' disease ${ }^{11-14}$, started to classify it as unexpected and expected, in order to consider just the first one as the true representative of this condition ${ }^{14}$. From our point of view, this differentiation has no clinical importance because, for prevention, its triggering mechanism is much more important than death expectancy. In Chagas' disease, whether the patient dies unexpectedly, with no signs or symptoms of the illness (unexpected sudden death),or the death is preceded by manifestations of the disease (expected sudden death), the final mechanism is usually the same, i.e., an arrhythmic event, most frequently ventricular fibrillation. In addition, in 
a retrospective more detailed investigation of chagasic patients with unexpected sudden death, Prata et al ${ }^{15}$ noticed previous cardiac symptoms (dyspnea, palpitations, seizures, and episodes of consciousness loss) in about $57 \%$ of the patients.

It is worth noting that from the qualitative point of view, gross and microscopic cardiac lesions of chagasic patients who died suddenly and who had no signs and or symptoms, of the disease, were very similar to those observed in patients with chronic Chagas' heart disease who died after a period of heart failure. Only from the quantitative point of view did differences occur, with lesions being less intense in chagasic patients who died suddenly ${ }^{16}$. Therefore, when we analyze the frequency of sudden death in Chagas' disease, we think that it is important to consider both events, the expected and the unexpected sudden deaths.

In regard to chronology of sudden death in Chagas' disease, we consider this the least relevant feature, because death almost always occurs instantaneously. Reports such as "He was all right, talking, and suddenly shouted 'My God' and died" or "As he/she did not wake up, I went to check and found him/her dead" or "He/she died suddenly, without saying a word", are common and reflect how fulminating the death is.

Supported by a wide literature review ${ }^{17-32}$, we have listed in table I the results of the major studies on causes of death and frequency of sudden death in different population subgroups of Chagas' disease. The careful analysis of these studies allowed the following conclusions: 1) sudden death, heart failure, and cerebral thromboembolism are the major causes of death in Chagas' disease; 2) the higher or lower frequency of a certain cause fundamentally depends on the characteristics of the population studied, with sudden death predominating in studies including only ambulatory patients $18,20,21,24,26,32$ or patients with ventricular arrhythmias ${ }^{27,30}$, and pump failure predominating in those studies carried out in hospitalized patients with cardiac decompensation ${ }^{17,23,29}$; and 3) even though death in chagasic patients is intrinsically associated with the degree of myocardial impairment, part of the cases of sudden death correspond to asymptomatic patients with mild electrocardiographic alterations and normal cardiac silhouette on X-ray ${ }^{19,20,28}$.

Therefore, on the basis of all these studies and considering the different evolutionary stages of the disease, we may state that sudden death accounts for about 55 to $65 \%$ of the deaths in Chagas' disease, heart failure for 25 to $30 \%$, and thromboembolic phenomena for the remaining 10 to $15 \%$.

\section{Clinical and epidemiological features}

Sudden death in the chagasic patient occurs mainly between 30 and 50 years of age, being rarer after the sixth decade of life, and predominates in males ${ }^{13,33,34}$. It usually happens during routine activities, physical exertion, or emotion, and is of the instantaneous type in around half of the cases. In the other half, death is preceded by premonito- ry symptoms for seconds and, rarely, for minutes ${ }^{13}$. Unlike ischemic heart disease, whose sudden death has a peak frequency during the morning, in Chagas' disease, a vespertine predominance seems to occur (from 12 am to $6 \mathrm{pm}$ ) ${ }^{35}$. In regard to the population affected, even though sudden death is more common in chagasic patients with complex ventricular arrhythmia or episodes of ventricular tachycardia, it may also be the first manifestation of the disease or its terminal event in patients with severe ventricular dysfunction and heart failure.

\section{Anatomopathological characteristics}

Despite the high prevalence of Chagas' disease in our country, systematized anatomopathological studies on chagasic patients with sudden death are scarce in the literature. In the few published studies ${ }^{16,36,37}$, we observe that from the qualitative point of view, cardiac lesions are very similar whether sudden death has occurred unexpectedly or not. Quantitatively, however, alterations in hearts of chagasic patients with unexpected sudden death are a lot more discrete than those found in chagasic patients who died after a period of heart failure.

Grossly, in unexpected sudden death, the shape of the heart is normal or slightly elongated due to a larger increase in the left ventricle as compared with the right ventricle; cardiac weight and volume are mildly to moderately increased, and the cavities are discretely dilated. On the other hand, in the chagasic patient with previous manifestations of cardiac decompensation, the heart has a globoid or conical shape, much greater weight and volume, and the cardiac cavities are very dilated, particularly the ventricles ${ }^{36}$.

From the microscopic point of view, the major lesions are focal or diffuse chronic inflammatory infiltration, mainly constituted by lynphomononuclear cells, the necrotic degenerative process, and fibrosis of substitution, which simultaneously affect the contractile myocardium, the specialized conducting tissue, and the intracardiac autonomic nervous system. Generally, these alterations are more discrete in chagasic patients with unexpected sudden death, as already pointed out, and the findings are similar to those of patients with the chronic form of Chagas' disease, who end up dying due to another mechanism ${ }^{16,37}$.

\section{Mechanisms of sudden death}

Confirmation of the exact mechanism of sudden death in Chagas' disease is extremely difficult and complex. This results from lack of electrocardiographic recordings in patients with sudden death as the first manifestation of the disease, from the extremely reduced number of deaths during ambulatory electrocardiographic monitoring, and from the inefficacy or nonexistence of specialized centers for attending victims of cardiopulmonary arrest out of the hospital environment in Latin America. Therefore, all reports on the mechanisms of sudden death in Chagas' disease are mainly 


\begin{tabular}{|c|c|c|c|c|c|c|c|c|}
\hline \multirow[t]{2}{*}{ Authors } & \multirow{2}{*}{$\begin{array}{c}\mathrm{N}^{\circ} \text { of } \\
\text { patients }\end{array}$} & \multirow{2}{*}{ Characteristics of the population studied* } & \multirow[t]{2}{*}{ Follow-up } & \multirow{2}{*}{$\begin{array}{l}\text { Deaths } \\
\text { related to } \\
\text { CD }\end{array}$} & \multicolumn{4}{|c|}{ Causes of death } \\
\hline & & & & & SD & CHF & $\mathrm{CS}$ & Others \\
\hline Prata, $1959^{17}$ & 169 & $\begin{array}{l}\text { - Hospital population } \\
\text { - Patients with decompensated HF }\end{array}$ & NR & 82 & $31(38)$ & $43(53)$ & - & $8^{\dagger}(9)$ \\
\hline Lima \& Rassi, $1962^{18}$ & 642 & $\begin{array}{l}\text { - Private patients } \\
\text { - } 100 \% \text { with abnormal ECG ( } 61 \% \text { with VEs) } \\
\text { - } 47 \% \text { with normal CS and } 53 \% \text { with enlarged CS (XR) }\end{array}$ & NR & 57 & $40(70)$ & $13(23)$ & $4(7)$ & - \\
\hline Porto, $1964^{19}$ & 503 & $\begin{array}{l}\text { - Private patients (endemic area) } \\
\text { - Normal ECG in 39\% of the patients } \\
\text { and abnormal in } 61 \% \text { of the patients }\end{array}$ & Up to 5-6 years & $96 \mid 1$ & $36(38)$ & $53(55)$ & - & $7^{\ddagger}(7)$ \\
\hline Brasil, $1965^{20}$ & 86 & $\begin{array}{l}\text { - Private patients } \\
\text { - 50\% with no apparent heart disease (subclinical form) } \\
\text { and } 50 \% \text { with heart disease }\end{array}$ & 10 years & $25^{\Re \mathbb{W I}}$ & $18(72)$ & $6(24)$ & $1(4)$ & - \\
\hline Baruffa, $1974^{21}$ & 172 & $\begin{array}{l}\text { - Population of endemic area (Rio Grande do Sul State) } \\
-23 \% \text { in the indeterminate; } 22 \% \text { in the digestive form; } \\
31 \% \text { in the cardiac form, and } 24 \% \text { in the cardiodigestive forr }\end{array}$ & rm & 18 & $10(56)$ & $8(44)$ & - & - \\
\hline Macedo, $1976^{22}$ & 840 & $\begin{array}{l}\text { - Population of endemic area } \\
\text { - Clinical and epidemiological investigation }\end{array}$ & 4 years & 24 & $9(38)$ & $14(58)$ & - & $1^{\S}(4)$ \\
\hline Pugliese et al, $1976^{23}$ & 160 & $\begin{array}{l}\text { - Patients with decompensated HF } \\
\text { - Revision of medical records }\end{array}$ & Up to 2.5 years & 96 & $10(10)$ & $63(66)$ & $1(1)$ & $22 !(23)$ \\
\hline Dias, $1982^{24}$ & 268 & - Pacientes with known acute phase & 27 years & 19 & $10(53)$ & $5(26)$ & $3(16)$ & $1^{\pi}(5)$ \\
\hline Espinosa et al, $1985^{25}$ & 104 & $\begin{array}{l}\text { - Ambulatory patients } \\
\text { - 29\% with normal ECG; 39\% with abnormal ECG, } \\
\text { Without CHF; and 32\% with abnormal ECG and severe CHF }\end{array}$ & 4.9 years & $36^{\# \#}$ & $15(42)$ & $16(44)$ & $5(14)$ & - \\
\hline Coura et al, $1985^{26}$ & 235 & $\begin{array}{l}\text { - Field patients } \\
\text { - Chronic chagasic patients }\end{array}$ & Up to 10 years & 41 & $31(76)$ & $9(22)$ & $1(2)$ & - \\
\hline Santana, $1987^{27}$ & 76 & $\begin{array}{l}\text { - Ambulatory patients (FC I or II) } \\
-19.5 \% \text { with normal ECG and } 81.5 \% \text { with abnormal ECG } \\
57 \% \text { with normal CS and } 43 \% \text { with enlarged CS (RX) }\end{array}$ & G 5.2 years & $14^{* * *}$ & $10(71)$ & $3(21)$ & $1(7)$ & \\
\hline Acquatella et al, $1987^{28}$ & 28755 & $\begin{array}{l}\text { - Ambulatory patients } \\
\text { - } 48 \% \text { with anormal ECG, } 12 \% \text { borderline, } \\
\text { and } 40 \% \text { abnormal } \\
\text { - } 79 \% \text { asymptomatic patients; } 13 \% \text { with mild/mod sympto } \\
\text { and } 8 \% \text { with severe CHF }\end{array}$ & 2.3 anos & $48^{\dagger \dagger}$ & $19(40)$ & $19(40)$ & $4(8)$ & $6^{\#}(12)$ \\
\hline Carrasco et al, $1994^{29}$ & $\begin{array}{l}185 \\
104\end{array}$ & $\begin{array}{l}\text { - Patients with abnormal ECG with no signs of CHF } \\
\text { - Patients with abnormal ECG and CHF }\end{array}$ & $\begin{array}{l}6.4 \text { years } \\
2.3 \text { years }\end{array}$ & $\begin{array}{l}33 \\
67\end{array}$ & $\begin{array}{l}12(36) \\
14(21)\end{array}$ & $\begin{array}{c}6(18) \\
52(78)\end{array}$ & $\begin{array}{c}12(36) \\
1(1)\end{array}$ & $\begin{array}{c}3^{* * *}(9) \\
-\end{array}$ \\
\hline Silva, $1997^{30}$ & 78 & $\begin{array}{l}\text { - Ambulatory or ward patients with NSVT on H } \\
\text { - } 85 \% \text { in FC I ou II e 15\% in FC III ou IV }\end{array}$ & 4.6 years & $21^{\text {赫 }}$ & $16(76)$ & $2(9.5)$ & $1(5)$ & $2^{\dagger \dagger}(9.5)$ \\
\hline Garzon, $1998^{31}$ & 987 & $\begin{array}{l}\text { Ambulatory or ward patients who underwent } \\
\text { hemodynamic study }\end{array}$ & 7 years & 331 & $169(51)$ & $147(44)$ & - & $15^{\text {市}(5)}$ \\
\hline Rassi Jr., $1999^{32}$ & 444 & Ambulatory patients (nonselected population) & 9.1 years & 111 & $74(67)$ & $23(21)$ & - & $14^{\$ \$}(12)$ \\
\hline $\begin{array}{l}\text { CS- cardiac silhouette; } \\
\text { heart failure; CHF- cons } \\
\text { tachycardia. * At the mo } \\
\text { and } 14 \text { pulmonary embol } \\
+\$ \text { thromboembolism; } \S \\
\text { ECG. IषI } 20 \% \text { of the dea } \\
\text { abnormal ECG and no C } \\
\text { patients with enlarged C } \\
\text { in patients with severe } C\end{array}$ & $\begin{array}{l}\text { ngestive h } \\
\text { noment of } \\
\text { olisms; I c } \\
\S \S \text { other c } \\
\text { eaths occu } \\
\text { CHF, and } \\
\text { CS, and } 86 \\
\text { CHF. } \$+\$\end{array}$ & $\begin{array}{l}\text { ebral stroke; FC- functional class; CD- Chagas' disease; EC } \\
\text { eart failure; mod - moderate; SD - sudden death; NR - not } \\
\text { patient inclusion in the study: } \dagger \text { unspecified causes; } \$ \text { extr } \\
\text { complication of megacolon; } \# \text { unknown causes; } * * \text { pulmonary } \\
\text { cardiovascular causes. II Approximately } 11 \% \text { of the deaths } \\
\text { arred in patients with no apparent heart disease, and } 80 \% \text { in } \\
\text { d } 78 \% \text { in patients with abnormal ECG and severe CHF. } * * * \\
6 \% \text { in FC II patients. } \dagger \dagger 15 \% \text { of the deaths occurred in asym } \\
\text { Approximately } 2 / 3 \text { of the deaths occurred in FC I/II patier }\end{array}$ & $\begin{array}{l}\text { treported; } \mathrm{P} \text {-pa } \\
\text { racardiac causes; } \\
\text { y thromboemboli } \\
\text { occurred in patie } \\
\text { patients with he } \\
\text { * All deaths occu } \\
\text { mptomatic patien }\end{array}$ & $\begin{array}{l}\text {; } \$ 1 \text { mese } \\
\text { s with norn } \\
\text { disease. \#\# } \\
\text { ed in patien } \\
25 \% \text { in pati } \\
\text { III/IV patie }\end{array}$ & $\begin{array}{l}\text { ECG, and } \\
2 \% \text { of the } \\
\text { with abnor } \\
\text { s with mild }\end{array}$ & $\begin{array}{l}\text { SVT - non } \\
\text { lon; i } 1 \text { Sto } \\
\text { oembolism } \\
89 \% \text { in pe } \\
\text { deaths occ } \\
\text { mal ECG; } \\
\text { d/moderate }\end{array}$ & $\begin{array}{l}\mathrm{H}-\mathrm{Hol} \\
\text { tained v } \\
\text { Adams, } \\
11 \text { proar } \\
\text { ts with } \\
\mathrm{d} \text { in pati } \\
\text { o of the } \\
\text { mptoms, }\end{array}$ & $\begin{array}{l}\text { Iter; HF - } \\
\text { entricular } \\
7 \text { shocks, } \\
\text { rhythmia; } \\
\text { abnormal } \\
\text { ients with } \\
\text { deaths in } \\
\text {, and } 60 \%\end{array}$ \\
\hline
\end{tabular}

based on observations, hypotheses, or inference ${ }^{38,39}$. Nevertheless, the essentially arrhythmogenic nature of chronic chagasic heart disease, which is mainly characterized by a high density and complexity of ventricular arrhythmias ${ }^{40-43}$, its fibrotic character, with akinetic or dyskinetic areas intermingled with preserved myocardial fibers ${ }^{44,45}$, and the reentrant mechanism of sustained ventricular tachycardia in a large number of cases on programmed ventricular stimulation $^{46-49}$, strongly suggest that ventricular fibrillation constitutes the terminal event in most cases of sudden death in Chagas' disease. Less frequently, a bradyarrhythmia ( sinus node dysfunction or total atrioventricular block) or electromechanical dissociation may be the cause of this event ${ }^{50}$.

Mendoza et $\mathrm{al}^{38}$, analyzing the Holter recording of 10 chagasic patients with ambulatory sudden death, identified ventricular fibrillation as the final event in 9 patients and bradyarrhythmia in only one. The precursor of ventricular fibrillation was torsade de pointes in 6 patients and sustained ventricular tachycardia in the 3 others. According to the authors, the high percentage of torsade de pointes may be explained by the coexistence in Chagas' heart disease of multiple abnormalities, such as disorders of conduction, sinus 
node dysfunction, diffuse fibrosis, primary and secondary alterations of ventricular repolarization, high frequency of ventricular arrhythmias, particularly polymorphic and in runs, lesions of cardiac nerve plexuses, and ventricular dysfunction, which may lead to heart failure. The possibility of the proarrhythmic effect should also be remembered, because all patients with torsade de pointes were on class IA antiarrhythmic drugs (quinidine and disopyramide). In our material, the analysis of 13,843 Holter recordings revealed only one case of sudden death (chagasic patient), in whom the final event was also ventricular fibrillation. In addition, during the innumerable opportunities to monitor the cardiac rhythm in chagasic patients with in-hospital cardiopulmonary arrest, ventricular fibrillation was undoubtedly the most frequent arrhythmia observed. These data, even though referring to a selected sample, stress the importance of ventricular fibrillation in the genesis of sudden death in chronic Chagas' heart disease.

Exceptionally, other mechanisms may lead to sudden death in Chagas' disease ${ }^{51-54}$, among which we can cite spontaneous ventricular rupture.

\section{Interaction of structural, functional, and triggering factors}

The classic biological model of sudden death proposed by Myerburg et al ${ }^{55}$, establishing three fundamental factors for occurrence of ventricular fibrillation, which are the arrhythmogenic substrate, the triggering factors (ventricular extrasystoles), and some functional factors, may also be applied to chronic Chagas' heart disease. Therefore, structural myocardial abnormalities, such as foci of inflammation, areas of fibrosis, ventricular dilation, and akinetic or dyskinetic areas, generate unidirectional block and slow conduction in circumscribed ventricular regions, essential for the appearance of reentrant ventricular arrhythmias, which are the main triggering factor of sudden death in chronic Chagas' heart disease. However, as not all chagasic patients with ventricular arrhythmia die suddenly, the model is probably only completed when some functional factors participate, causing myocardial instability and thus favoring installation of fatal arrhythmias, such as ventricular fibrillation (fig. 1). Acute hemodynamic deterioration, hypoxemia, electrolytic disorders, the use of medications with a proarrhythmic potential, and mainly changes in the autonomic nervous system ${ }^{56-58}$ are examples of factors that may cause the arrhythmogenic substrate to be unstable. This is the reason why significant morphological differences are not found, from the qualitative point of view (grossly and microscopically), when comparing hearts of chagasic patients who died suddenly with hearts of chagasic patients dying during evolution of heart failure.

\section{Identification of groups at risk}

Mortality due to Chagas' disease is still very significant in several Latin American countries and is strictly rela-

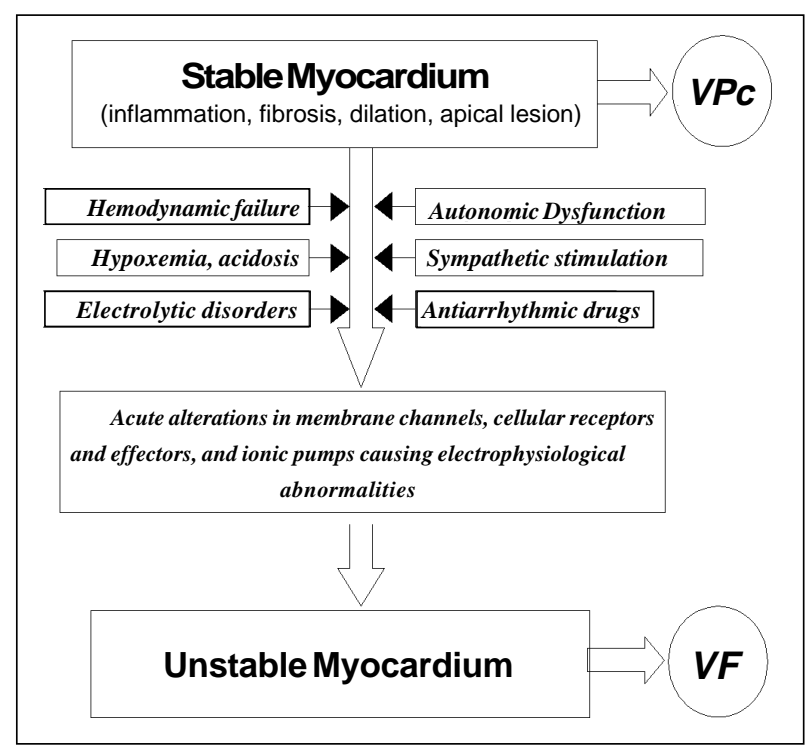

Fig. 1 - Instability of structurally abnormal myocardium through the interaction of different functional modulators, resulting in ventricular fibrillation. VPC - ventricular premature contraction; VF - ventricular fibrillation.

ted to the presence of heart disease. The risk of sudden death is obviously not the same for every chagasic patient; therefore, several authors ${ }^{25,27,29,30-32,50,59-72}$ have tried to identify factors predisposing certain patients to a higher risk of this catastrophic event. Therefore, variables, such as presyncope and syncope, ventricular dysfunction and heart failure, complex nonsustained and sustained ventricular arrhythmias, severe bradyarrhythmias (sinus node dysfunction and advanced atrioventricular blocks), and previous cardiac arrest have been identified as predictors of the risk of sudden death, at least in some studies. These risk predictors can be classified as major or minor predictors, as shown in table II. Other variables, such as simple ventricular arrhythmia on Holter ${ }^{27,29,68}$ and the complete right bundlebranch block ${ }^{59}$, at least when isolated, do not negatively influence the prognosis of chronic chagasic heart disease.

Presyncope and syncope are common symptoms in chronic chagasic heart disease and may be caused either by brady- or tachyarrhythmias. Aiming to know the prevalence of these symptoms and to correlate them with the presence of cardiac arrhythmias, 143 chronic chagasic patients during outpatient visits were asked about the presence of symptoms and underwent 24-hour Holter monitoring so that their arrhythmias could be studied ${ }^{64}$. Presyncope or syncope were reported by $20(14 \%)$ patients, of whom $80 \%$ had episodes of nonsustained ventricular tachycardia and 30\% had bradyarrhythmias (sinus node dysfunction or atrioventricular block), showing the high prevalence of severe arrhythmias in these situations. A study by Rassi et al ${ }^{62}$ comprised 45 chronic symptomatic chagasic patients, who underwent electrophysiological study because of presyncope (17 patients) or syncope (28 patients), and whose cause was not clarified by noninvasive methods. These authors evidenced induction of sustained ventricular tachycardia in $36 \%$ of the patients with syncope and in $6 \%$ of the patients with presyncope, and disorder of the sinus node or lesion of 


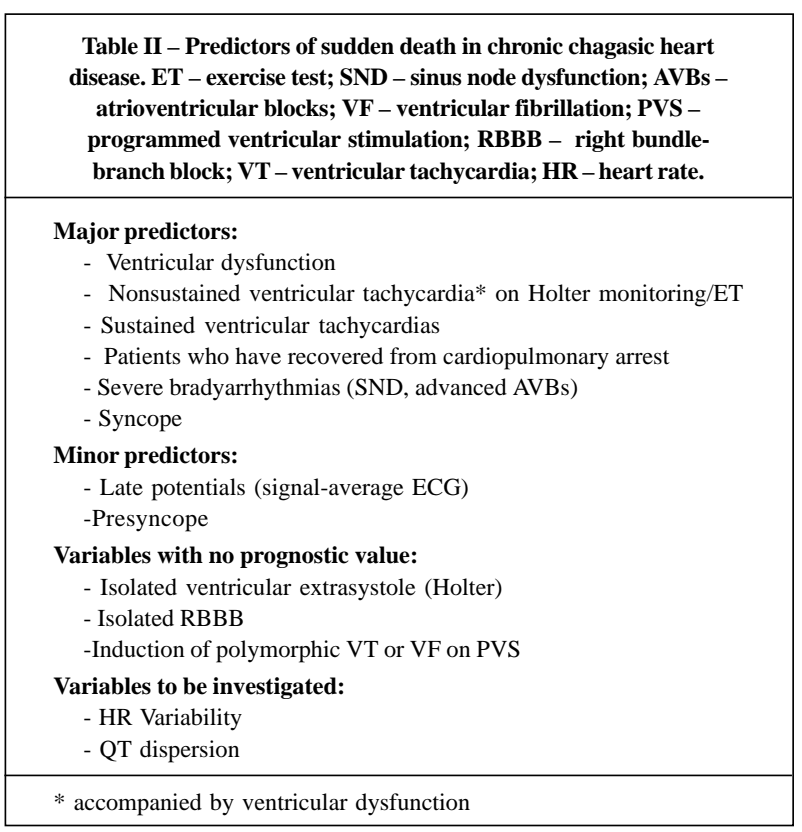

His-Purkinje in $39 \%$ of the patients with syncope and in $41 \%$ of those with presyncope.

Martinelli et al ${ }^{67}$ used noninvasive methods to study 53 consecutive patients with recurrent syncope of unknown mechanism and found abnormalities in 36 (68\%) patients. Sustained ventricular tachycardia was induced in 15 (28\%) patients, the HV interval was altered (greater than $70 \mathrm{~ms}$ ) in $11(21 \%)$ patients, and $10(19 \%)$ patients had both alterations, induced ventricular tachycardia and increased HV interval. On the basis of these results, the patients were treated with implantation of atrioventricular pacemakers antiarrhythmic drugs, and or, empirically or guided by electrophysiological study. During a mean follow-up of 85 months, $9(17 \%)$ patients died suddenly, and $15(28 \%)$ had recurrence of the syncope.

Complex ventricular arrhythmias, which are frequent in chronic Chagas' heart disease, also constitute major risk factors for sudden death, mainly when associated with impairment of ventricular function. Aiming to study the longterm prognosis of nonsustained ventricular tachycardia and ventricular dysfunction, 444 patients in our service underwent echocardiography and 24-hour Holter monitoring ${ }^{32}$. After a mean follow-up of 9 years, 132 patients had died (sudden death in 74 patients, congestive heart failure in 23 patients, other cardiovascular causes in 14 patients, noncardiovascular causes in 19 patients, and unknown mechanism in 2 patients). Classification of the patients in 4 subgroups according to the presence of nonsustained ventricular tachycardia and ventricular dysfunction revealed the poor prognosis for those with the two risk factors, an intermediate survival for those with only one of the risk factors, and a good prognosis for those with no ventricular tachycardia and no ventricular dysfunction.

Santana ${ }^{27}$, in a longitudinal study comprising 76 chronic chagasic patients, reported an actuarial probability of 7-year survival of $48.0 \pm 10.8 \%$ in patients with nonsus- tained ventricular tachycardia on Holter monitoring and of $29.5 \pm 12.9 \%$ in those patients with nonsustained ventricular tachycardia and cardiomegaly on the roentgen examination; on the other hand, the prognosis was good for those patients with simple ventricular arrhythmias. Similar results have been reported by other authors ${ }^{29,68}$.

Rassi ${ }^{60}$, following up patients with sustained ventricular tachycardia, reported a mortality of $93 \%$ in 8 years, with more than $70 \%$ of the deaths occurring in the first two years of follow-up. It is worth noting that sudden death accounted for $71 \%$ of the deaths in Santana's study and for 90\% of the deaths in Rassi's study.

Presence of ventricular tachycardia during exercise testing also accounts for a higher risk of sudden death in chagasic patients. In the study by De Paola et al ${ }^{71}$, comprising 69 chagasic patients consecutively examined, after a mean 24-month follow-up, sudden death was observed in $16 \%$ of the 44 patients who had ventricular tachycardia during the exercise test; on the other hand, none of the 25 patients without ventricular tachycardia died suddenly.

In regard to the importance of functional class and ventricular dysfunction, Mady et al ${ }^{69}$, in a 3-year follow-up of 104 chagasic male patients with heart failure, reported an excellent prognosis for functional class II patients ( $97 \%$ of survival), a reasonable prognosis for functional class III patients (58\% of survival), and a very poor prognosis for functional class IV patients (only 16\% of survival). Likewise, the 3 -year survival probability was $100 \%$ when the ejection fraction was higher than 0.50 , dropping to $70 \%$ in the patients with ejection fraction between 0.31 and 0.50 , and decreasing to only $16 \%$ in those patients with ejection fraction equal to or lower than 0.30 . However, in this study, the authors do not mention the causes of death.

Rassi et al ${ }^{50}$, analyzing the natural history of total atrioventricular block, found a survival of only $33 \%$ in 147 untreated chagasic patients, who were followed up for a mean period of 3.6 years. In most of the cases ( $86 \%$ ), death was sudden.

Two other methods of investigation, signal-averaged electrocardiography and programmed ventricular stimulation, have been used to identify high-risk patients. Signalaveraged electrocardiography allows the diagnosis of late potentials, which are considered noninvasive markers of electrophysiological substrate for reentrant ventricular arrhythmias. Moraes et al ${ }^{66}$, studying the prevalence of late potentials in 192 patients with chronic Chagas' heart disease and their relation with sustained ventricular tachycardia, observed in the group with no bundle-branch block a higher prevalence of late potentials in the patients with sustained ventricular tachycardia, as compared with those without tachycardia ( $78 \%$ vs $31 \%, \mathrm{p}<0.001$ ). However, in the patients with bundle-branch block, this distinction could not be made (late potential present in $67 \%$ of the patients with sustained ventricular tachycardia and in $48 \%$ of the patients without tachycardia, $\mathrm{p}=0.07$ ), confirming the lower usefulness of late potentials in chagasic patients with bundle-branch block. During a mean 40-month follow-up, 12 
(21\%) patients had recurrence of sustained ventricular tachycardia, $92 \%$ of whom had late potentials.

In the last few years, invasive electrophysiology ${ }^{65}$ has appeared as an important method for assessing and managing patients at high risk for developing sudden death, particularly those recovering from cardiopulmonary arrest and those with recurrent episodes of sustained ventricular tachycardia. More recently, Silva ${ }^{30}$ assessed the prognostic value of inducing ventricular tachycardia by programmed ventricular stimulation in 78 chagasic patients with nonsustained ventricular tachycardia on Holter, mean ejection fraction of $0.47 \pm 0.18$, and no clinical history of sustained arrhythmias. Sustained monomorphic ventricular tachycardia was induced in 25 (32\%) patients, who required treatment with class III antiarrhythmic drugs, 24 with amiodarone and only one with sotalol. After a mean follow-up of 56 months, the accumulated probability of survival ( $62 \%$ vs $24 \%)$ and the event-free proportion - cardiac death, spontaneous sustained ventricular tachycardia, and recurrence of syncope-were significantly higher in noninducible patients as compared with the inducible ones (50\% vs $12 \%$ ). On the other hand, induction of polymorphic ventricular tachycardia or ventricular fibrillation had no prognostic significance, and it may be an unspecific ventricular response. This fact has also been reported by Rassi et al ${ }^{63}$.

Finally, technological advances have allowed the appearance of new methods of risk stratification, among which we cite the study of heart rate variability and the analysis of dispersion of the QT interval. These are noninvasive methods that assess the influence of the autonomic nervous system on the electrophysiological properties of the heart. As the sympathovagal balance is essential for maintaining myocardial electrical stability, changes in the balance between the parasympathetic and sympathetic autonomic activities may increase ventricular excitability and trigger fatal arrhythmias, such as ventricular fibrillation. Therefore, according to some experimental and clinical studies ${ }^{73-75}$, both reduction in variability of heart rate expressed by different parameters in time and frequency domain, and the increase in ventricular repolarization dispersion, which translates nonuniform recovery of ventricular excitability, were associated with a higher risk of developing ventricular tachyarrhythmias and sudden death, particularly after myocardial infarction. The frequent pathological involvement of the autonomic nervous system in Chagas' heart disease ${ }^{76}$ turns these two new methods into promising tools for identifying patients at high risk for sudden death ${ }^{77}$.

\section{Relation between risk and total number of sudden death in Chagas' disease}

According to unofficial statistics, around 50,000 deaths due to Chagas' disease occur every year, $60 \%$ of which are sudden. As 16 to 18 million chagasic individuals exist in Latin America, the annual rate of sudden death may be estimated in 0.17 to $0.19 \%$ (approximately $2 / 1,000$ ). Therefore, to prevent two cases of sudden death in the chagasic popula- tion, any intervention should also be applied to 998 more individuals who would not have any other event in a one-year period, making this strategy unnecessary when the costbenefit relation is taken into account. If we consider that sudden death in the chagasic patient is closely related to the presence of heart disease, and that usually 20 to $30 \%$ of the chagasic patients develop some degree of cardiac impairment during the infection, the annual rate of sudden death in chagasic patients with heart disease increases to 0.56 to $0.94 \%$. However, this rate is still not expressive and does not justify an intervention in an indiscriminate manner in all patients. Therefore, it is essential to identify subgroups at higher risk for sudden death, which may be obtained as some variables, such as ventricular dysfunction, complex ventricular arrhythmias, induction of ventricular tachycardia, and previous cardiopulmonary arrest, are recognized. As can be observed in figure 2, as subgroups at higher risk are identified, the absolute figure corresponding to sudden deaths progressively decreases. Individuals with heart disease and a high probability of sudden death may be identified, but they represent only a small part of the total number of sudden deaths observed in the chagasic population as a whole.

These data impose some limits on prevention of sudden death in Chagas' disease in an indiscriminate manner. As the risk of sudden death among chagasic individuals as a whole or among those with heart disease is not high, any intervention to large-scale prevention should be applied to a huge contingent of individuals who will never develop any event, in an attempt to benefit a minority that will have it. On the other hand, even though adopting therapeutical measures only in subgroups at high risk (patients with sustained ventricular tachycardia or recovering from cardiac arrest) may spare many lives among treated individuals (assuming an effective antiarrhythmic therapy exists), it has a small impact on reducing the total number of sudden deaths. Therefore, we believe that from the epidemiological point of view and considering the cost-benefit relation, we should focus on the subgroups at intermediate risk that have a reasonable number of fatal events, i.e., those chagasic individuals with some degree of myocardial impairment and associated complex ventricular arrhythmias.

\section{Primary and secondary prevention of sudden death}

The essentially arrhythmogenic nature of chronic Chagas' heart disease and evidence that certain types of arrhythmias, particularly complex ventricular arrhythmias, predispose to sudden death, have motivated several researchers to use different antiarrhythmic drugs with prophylactic aims. Therefore, therapeutical assays with drugs of the classes IA, IB, IC, and III were carried out ${ }^{78-87}$ and, in almost all of them, efficacy of the antiarrhythmic drugs on ventricular arrhythmias was observed. However, as suppression of ectopic ventricular beats does not necessarily imply a reduction in mortality ${ }^{88-90}$, when we choose to routinely admi- 


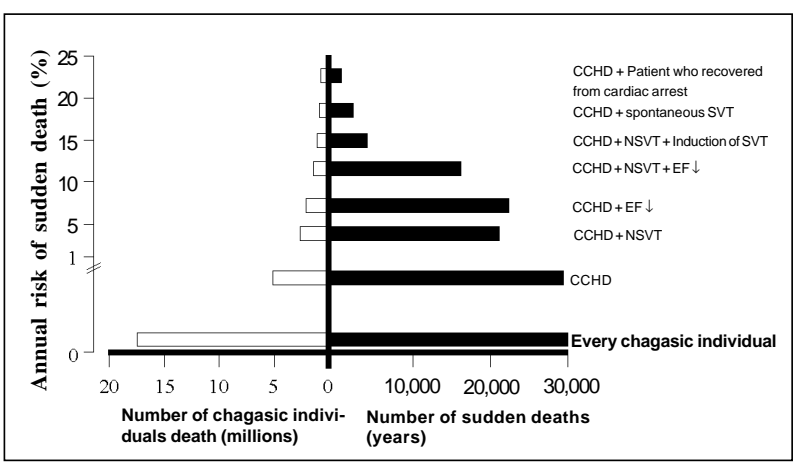

Fig. 2 - Relation between risk and absolute number of sudden deaths in different population subgroups with Chagas' disease. The annual risk of sudden death in the entire chagasic population, which comprises approximately 17 million individuals, is around 0.15 to $0.20 \%$, accounting for and 30,000 deaths per year. With the inclusion of additional risk predictors, the chagasic population becomes more selective and the risk of sudden death increases gradually. However, this higher risk of sudden death in specific subgroups is accompanied by a progressive decrease in the total number of annual sudden deaths. Therefore, an inverse relation exists between the risk of sudden death and the total number of fatal events, making difficult the adoption of preventive measures in large scale. CCHD - chronic Chagas' heart disease; EF- ejection fraction; NSVT - nonsustained ventricular tachycardia; SVT - sustained ventricular tachycardia

nister antiarrhythmic drugs to chagasic patients with complex ventricular arrhythmias, we should know that it is possible to reduce the incidence of sudden death with the prophylactic treatment. Results of several prospective randomized studies ${ }^{91-96}$ and two recent metaanalyses ${ }^{97,98}$ carried out in patients with other types of heart disease, such as ischemic and dilated (idiopathic) heart disease, show that amiodarone, unlike class I antiarrhythmic drugs, may prevent sudden death and also decrease total mortality in high-risk patients with complex ventricular arrhythmias or heart failure, or both. Extrapolating these data to chronic Chagas' heart disease, about which proper therapeutical assays are lacking, we believe that administration of amiodarone to chagasic patients with complex ventricular arrhythmias is totally justified, particularly when the arrhythmia in question is nonsustained ventricular tachycardia accompanied by ventricular dysfunction. In addition to reducing mortality, amiodarone has an extraordinary antiectopic efficacy ${ }^{82,84,85,87}$, a low incidence of significant side effects 99,100 and proarrhythmia ${ }^{101}$, particularly when administered in low doses, and, only exceptionally, does it change inotropism. Therefore, amiodarone may be used even in severe impairment of ventricular function, including the treatment of decompensated heart failure, which in chronic Chagas' heart disease is accompanied by complex ventricular arrhythmia in almost all cases ${ }^{43}$. In chagasic patients with nonsustained ventricular tachycardia and preserved ventricular function, because the risk of sudden death seems to be lower, the most adequate management, currently, seems to be not to use prophylactic antiarrhythmic drugs. Another option would be the use of new noninvasive investigative methods, such as signal-averaged electrocardiography and heart rate variability for a better risk stratification in these cases.

In patients with sustained ventricular tachyarrhythmias, amiodarone is also the treatment of choice. Rassi ${ }^{102}$ analyzed the actuarial curve of survival of 34 patients with sustained monomorphic ventricular tachycardia empirically treated with amiodarone isolated or associated with other antiarrhythmic drugs. He compared this curve with that of 42 untreated patients or patients who had used procainamide or quinidine, the only drugs available on the market at that time, and he observed a significantly higher survival in the group treated with amiodarone. After 1, 4, and 8 years of follow-up, survivals were respectively $87 \%, 65 \%$, and $59 \%$ for the group of patients treated with amiodarone, and $57 \%$, $22 \%$, and $7 \%$ for the group of untreated patients or patients treated with class I antiarrhythmic drugs ( $p<0.01$, fig. 3A).

Scanavacca et al ${ }^{103}$, following up 35 chagasic patients with sustained ventricular tachycardia empirically treated with amiodarone, also found good results with an estimated probability of sudden death of only $11 \%$ in 3 years, even though recurrence of arrhythmia had been relatively frequent, predominating in patients with severe ventricular dysfunction. These data support the defibrillating effect of amiodarone.

Sotalol, which has been more recently marketed in Brazil, has also been used for treating sustained ventricular tachycardia of chronic Chagas' heart disease ${ }^{104}$. However, no studies exist assessing the effects of sotalol on reducing mortality.

Finally, ventricular tachycardia may be recurrent and refractory to medicamentous treatment in some cases. In these patients, the nonpharmacological treatment, such as percutaneous catheter ablation, surgical ablation, implantation of automatic cardioverter/defibrillator, or other surgical procedures may be attempted. The choice of treatment will be determined at first by the capacity for reproducing or not the clinical arrhythmia on the electrophysiological study, which is an examination always indicated in these situations. Inducing hemodynamically stable and well-tolerated sustained ventricular tachycardia allows the identification of the site of origin of tachycardia through different mapping techniques, and then the directed procedures, i.e., surgical or catheter ablation, may be chosen.

At first, surgical ablation should be considered when the ejection fraction is not significantly impaired, the surgical risk is low, and especially when associated surgical procedures, such as aneurysmectomy, are indicated. Magalhães et al ${ }^{105}$ introduced the technique of interpapillary endomyocardial cryoablation with no previous electrophysiological mapping to be applied to patients with sustained ventricular tachycardia and akinesia or dyskinesia of the inferolateral region of the left ventricle, where the reentrant circuit of tachycardia is most commonly situated, according to observations in his group of work and those of Takehara et al ${ }^{106}$. Initial results with this procedure proved efficacious in approximately $60 \%$ of the cases.

Catheter ablation may be performed in patients with depressed ventricular function, because the risk inherent to the procedure is lower. It is worth noting that reproduction of monomorphic sustained ventricular tachycardia in chronic Chagas' heart disease has been reported in 63 to $95 \%$ of the cases ${ }^{46-49}$. Reentry has been considered the major electrophysiological mechanism, and focal areas of fibrosis or 


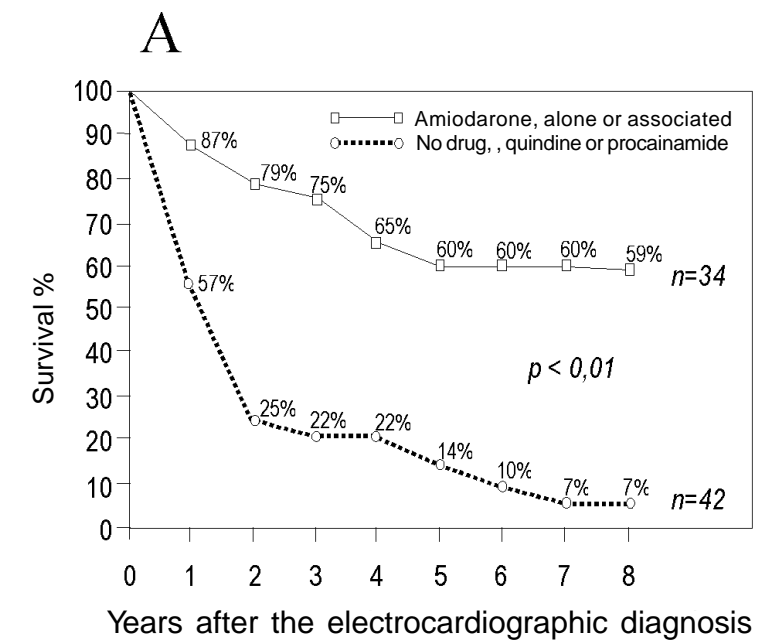

B

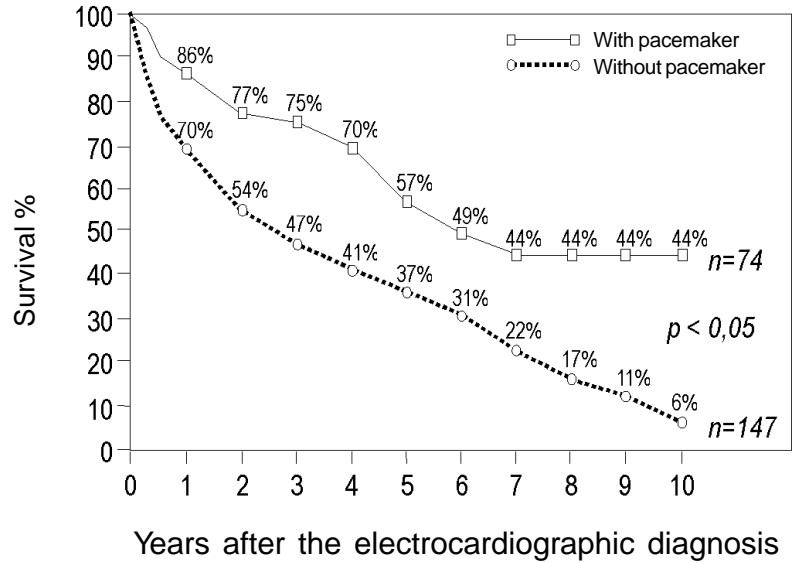

Fig. 3 - Actuarial curves of survival in chronic Chagas' heart disease. (A) Sustained ventricular tachycardia. (B) Total atrioventricular block.

perianeurysmatic zones constitute the anatomical basis for the arrhythmogenic substrate.

The first successful ablation of chagasic ventricular tachycardia was reported in 1987 by Sosa et al ${ }^{107}$. However, subsequent results using radiofrequency proved deceptive (unpublished data of several authors). This may be due to the fact that in chronic Chagas' heart disease the arrhythmogenic substrate is usually extensive, macroreentrant, and epimyocardial rather than subendocardial, making the conventional application of radiofrequency pulses in the subendocardial region ineffective.

In our institution, since 1991, 55 patients (49 chagasics), of whom $55 \%$ with recurrent and refractory sustained ventricular tachycardia, $23,5 \%$ with syncopal ventricular tachycardia, $14,5 \%$ with incessant ventricular tachycardia, and $2 \%$ with an implartable defibrillator and frequent shocks were treated with catheter ablation using eletric energy of direct current. We obtained immediate success (no reinduction of tachycardia) in $74 \%$ of the mapeable tachycardias that were ablated. After a mean follow up of 42 months, 14 (25,5\%) patients died (one during the procedure), 7 (12,5\%) had recurrences, $11(20 \%)$ were lost to follow-up, and $23(42 \%)$ are alive and doing well. It is worth noting that except for one patient, all the others continue to use antiarrhythmic drugs..

More recently, Sosa et al ${ }^{109,110}$ reported the technique of epicardial mapping through pericardial puncture and epicardial application of radiofrequency performed in the hemodynamic laboratory, with encouraging results.

In regard to implantation of the automatic cardioverter/defibrillator ${ }^{111}$, it is the treatment of choice for survivors of cardiac arrest with inducible ventricular fibrillation or symptomic and intolerant sustained ventricular tachycardia during the electrophysiological study, or when one cannot reproduce the spontaneous arrhythmia, situations that make the mapping of the arrhythmogenic area impossible. Unsuccessful cases or cases refractory to the ablation techniques also constitute indications for using these devices.
The appearance of transvenous cardioverter/defibrillators ${ }^{112}$, reducing morbidity and mortality related to their implantation, and the lower current cost of antiarrhythmic devices have allowed a wider use of these systems in our country. It is worth noting that the most modern devices may release several types of stimulation, such as antitachycardia, low-energy cardioversion, and high-energy defibrillation shocks, and may also function as an antibradycardia pacemaker. In addition, we have multiprogramming options for detecting tachycardia and the capacity for storing information regarding the interventions of the device.

The use of antiarrhythmic drugs after implantation of the automatic cardioverter/defibrillator is usually necessary to eliminate intermittent episodes of arrhythmias that may result in inadequate activation of the device, and also to slow an eventual tachycardia crisis, improving its hemodynamic tolerance and making its interruption through antitachycardiastimulation easy.

Among other surgical procedures, electrophysiologically oriented subendocardial resection, associated or not with cryoablation, is worth noting ${ }^{113}$. Nondirectional conventional ventricular aneurysmectomy is not recommended due to its low success index, because the origin of the ventricular tachycardia usually is not related to the site of the aneurysm, particularly when it is apical ${ }^{114}$.

Another measure that may help prevent chagasic sudden death is implantation of a definite cardiac pacemaker in every symptomatic or high-risk bradyarrhythmia. It improves the quality of life of symptomatic patients and increases survival, even in the presence of cardiomegaly and heart failure. Rassi ${ }^{102}$, analyzing the natural history of total atrioventricular block in 147 chagasic patients without pacemaker implantation, found survivals of $70 \%, 37 \%$, and $6 \%$ after 1,5 , and 10 years of follow-up. On the other hand, in patients who underwent pacemaker implantation, of the VVI type, survival was significantly greater $(86 \%, 57 \%$, and 
$44 \%$, respectively) (Fig. 3B). Sudden death accounted for $87 \%$ of the deaths of patients without pacemakers and $67 \%$ of the deaths of patients with pacemakers.

\section{Final considerations}

In conclusion, the symptomatic or asymptomatic chagasic patient with confirmed or suspected arrhythmia and, particularly with any degree of myocardial dysfunction, should be carefully assessed, at first with noninvasive me- thods and, whenever necessary, complemented by invasive electrophysiological evaluation. If ventricular arrhythmia with prognostic significance is detected, its therapeutical control, at first medicamentous, should be pursued and reassessed, and the refractory cases should undergo special procedures. In the case of significant bradyarrhythmia, implantation of a definite cardiac pacemaker is mandatory. This is how we expect to reduce the number of sudden deaths, a common occurrence in chronic Chagas' heart disease, which affects people in the most productive phase of their lives.

\section{References}

1. Chagas C. O Mal de Chagas. Archivos da Sociedade de Medicina e Cirurgia de São Paulo 1912; 3: 34-66.

2. Chagas $C$, Villela E. Forma cardíaca da Trypanosomiase Americana. Mem Inst Oswaldo Cruz 1922; 14: 5-61.

3. WHO. Control of Chagas Disease. Geneva. WHO Technical Report Series 1991; 811: 95p.

4. Spain DM, Bradess VA, Mohr C. Coronary atherosclerosis as a cause of unexpected and unexplained death. An autopsy study from 1949-1959. JAMA 1960; 174: 384-8.

5. Burch GE, DePasquale NP. Sudden, unexpected, natural death. Am J Med Sci 1965; 249; 86-96.

6. Gordon T, Kannel WB. Premature mortality from coronary heart disease. JAMA 1971; 215: 1617-25.

7. Kannel WB, Doyle JT, McNamara PM, Quickenton P, Gordon T. Precursors of sudden coronary death. Factors related to the incidence of sudden death. Circulation 1975 ; 51 : 606-13

8. Virmani R, Roberts WC. Sudden cardiac death. Hum Pathol 1987; 18: 485-92.

9. Goldstein S, Moss AJ, Greene W. Sudden death in acute myocardial infarction. Arch Intern Med 1972; 129: 720-4.

10. Paul O, Schatz M. On sudden death. Editorial. Circulation 1971; 43: 7-10.

11. Chapadeiro E, Lopes ER, Raso P, Brauna AO. Importância do reconhecimento da Doença de Chagas em Medicina Legal. O Hospital 1969; 76: 249-57.

12. Lopes ER, Chapadeiro E. Morte súbita em área endêmica da Doença de Chagas. Rev Soc Bras Med Trop 1983; 16: 79-84.

13. Prata A, Lopes ER, Chapadeiro E. Morte súbita. In: Cançado JR, Chuster M, eds. Cardiopatia Chagásica. Belo Horizonte: I. Oficial 1985: 114-20.

14. Storino R, Milei J. Complicaciones. In: Storino R, Milei J, eds. Enfermedad de Chagas. Buenos Aires: Mosby, 1994: 483-502.

15. Prata A, Lopes ER, Chapadeiro E. Características da morte súbita tida como não esperada na Doença de Chagas. Rev Soc Bras Med Trop 1986; 19: 9-12.

16. Lopes ER, Chapadeiro E, Almeida HO, Rocha A. Contribuição ao estudo da anatomia patológica dos corações de chagásicos falecidos subitamente. Rev Soc Bras Med Trop 1975; 9: 269-82.

17. Prata A. Prognóstico e complicações da doença de Chagas. Rev Goiana Med 1959; 5: 87-96

18. Lima AB, Rassi A. Parasitic heart diseases. In: Luisada AA, ed. Cardiology. New York: McGraw-Hill, 1962(suppl. 1, part 8): 100-19.

19. Porto CC. O eletrocardiograma no prognóstico e evolução da doença de Chagas. Arq Bras Cardiol 1964; 17: 313-46.

20. Brasil A. Evolução e prognóstico da doença de Chagas. Arq Bras Cardiol 1965; 18: $365-80$.

21. Baruffa G. Contribuição ao conhecimento da forma crônica da doença de Chagas na zona sul do Rio Grande do Sul. R AMRIGS 1974; 18: 237-50.

22. Macedo VO. Influência da exposição à reinfecção na evolução da doença de Chagas. Rev Pat Trop 1976; 5: 33-115.

23. Pugliese C, Lessa I, Santos Filho A. Estudo da sobrevida na miocardite crônica de Chagas descompensada. Rev Inst Med Trop São Paulo 1976; 18: 191-201.

24. Dias JCP. Doença de Chagas em Bambuí, Minas Gerais, Brasil. Estudo clínicoepidemiológico a partir da fase aguda, entre 1940 e 1982 (Tese). Belo Horizonte: UFMG, 1982: 376p.

25. Espinosa R, Carrasco HA, Belandria F, et al. Life expectancy analysis in patients with Chagas'disease: prognosis after one decade (1973-1983). Int J Cardiol 1985; 8: 45-56

26. Coura JR, Abreu LL, Pereira JB, Willcox HP. Morbidade da Doença de Chagas. IV.
Estudo longitudinal de dez anos em Pains e Iguatama, Minas Gerais, Brasil. Mem Inst Oswaldo Cruz 1985; 80: 73-80.

27. Santana OO. Arritmia ventricular e evolução clínica de pacientes na fase crônica da doença de Chagas (Dissertação de Mestrado). Salvador: Universidade Federal da Bahia, 1987: 50p.

28. Acquatella H, Catalioti F, Gomez-Mancebo JR, Davalos V, Villalobos L. Long-term control of Chagas disease in Venezuela: effects on serologic findings, electrocardiographic abnormalities, and clinical outcome. Circulation 1987; 76: 556-62.

29. Carrasco HA, Parada H, Guerrero L, Duque M, Durán D, Molina C. Prognostic implications of clinical, electrocardiographic and hemodynamic findings in chronic Chagas' disease. Int J Cardiol 1994; 43: 27-38.

30. Silva RMFL. Valor preditivo das variáveis clínicas e eletrofisiológicas nos pacientes com cardiopatia chagásica crônica e taquicardia ventricular não-sustentada - Análise terapêutica - (Tese). São Paulo: Escola Paulista de Medicina da Universidade Federal de São Paulo, 1997: 147p.

31. Garzon SAC, Lorga AM, Jacob JLB, et al. Predictors of mortality in chronic Chagas heart disease - long-term follow-up of 987 subjects for up to 22 years. $\mathbf{J}$ Am Coll Cardiol 1998; 31(suppl C): 107C

32. Rassi Jr A, Waktare JEP, Rassi SG, et al. Chagas heart disease: long term prognostic significance of nonsustained ventricular tachycardia and left ventricular dysfunction. PACE 1999; 22(Part II): 862 .

33. Menezes M, Rocha A, Silva AC, Silva AM. Causas básicas de morte em chagásicos idosos. Arq Bras Cardiol 1989; 52: 75-8.

34. Bestetti RB, Freitas OC, Muccillo G, Oliveira JSM. Clinical and morphological characteristics associated with sudden cardiac death in patients with Chagas' disease. Eur Heart J 1993; 14: 1610-14.

35. Lopes ER, Cunha LFLR, Santos TAM, et al. Variações circadianas diárias e semanais na morte súbita da Doença de Chagas. Arq Bras Cardiol 1993; 61: 345-8.

36. Lopes ER, Chapadeiro E, Tafuri WL, Almeida HO, Abraão D. Pêso do coraçãoe tipo de morte no chagásico crônico. Rev Inst Med Trop São Paulo 1970; 12: 293-7.

37. AndradeZ, Lopes ER, Prata SP. Alterações do sistema de condução do coração em chagásicos acometidos de morte repentina. Arq Bras Cardiol 1987; 48: 5-9.

38. Mendoza I, Moleiro F, Marques J. Morte súbita na doença de Chagas. Arq Bras Cardiol 1992; 59: 3-4

39. Fuenmayor AJ, Fuenmayor P. Muerte súbita en pacientes com miocarditis chagásica. Arch Inst Cardiol Méx 1996; 66: 157-61.

40. Chiale PA, Halpern S, Nau GJ, et al. Malignant ventricular arrhythmias in chronic chagasic myocarditis. PACE 1982; 5: 162-72.

41. Guerrero L, Carrasco H, Parada H, MolinaC, Chuecos R. Mecanica ventriculary arritmias cardiacas en pacientes chagasicos y com miocardiopatias dilatadas primarias. Seguimiento eco-electrocardiografico. Arq Bras Cardiol 1991; 56: 465-9.

42. Elizari MV, Chiale PA. Cardiac arrhythmias in Chagas' heart disease. J Cardiovasc Electrophysiol 1993; 4: 596-608.

43. Rassi Jr A, Rassi AG, Rassi SG, Rassi JrL, Rassi A. Arritmias ventriculares na doença de Chagas. Particularidades diagnósticas, prognósticas e terapêuticas. Arq Bras Cardiol 1995; 65: 377-87.

44. Barretto ACP, Higuchi ML, Luz PL, et al. Comparação entre alterações histológicas da miocardiopatia da doença de Chagas e cardiomiopatia dilatada. Arq Bras Cardiol 1989; 52: 79-83.

45. Lopes ER, Chapadeiro E. Patogenia das manifestações cardíacas na doença de Chagas. Arq Bras Cardiol 1995; 65: 367-75.

46. Mendoza I, Camardo J, Moleiro F, et al. Sustained ventricular tachycardia in chronic myocarditis: electrophysiologic and pharmacologic characteristics. Am J Cardiol 1986; 57: 423-7 
47. De Paola AAV, Horowitz LN, Miyamoto MH, et al. Angiographic and electrophysiologic substrates of ventricular tachycardia in chronic chagasic myocarditis. Am J Cardiol 1990; 65: 360-3.

48. Giniger AG, Retyk EO, Laiño RA, Sananes EG, Lapuente AR. Ventricular tachycardia in Chagas' disease. Am J Cardiol 1992; 70: 459-62.

49. Sarabanda A, Sosa E, Scanavacca M, et al. Características da indução da taquicardia ventricular sustentada durante a estimulação ventricular programada na cardiopatia chagásica crônica. Arq Bras Cardiol 1994; 63(supl I): 124.

50. Rassi A, Rassi Jr A, Faria GHDC, et al. História natural do bloqueio atrioventricular total de etiologia chagásica. Arq Bras Cardiol 1992; 59(supl II): 191

51. Oliveira JS, Barbieri Neto J. Cardiopatia chagásica. "Aneurisma da ponta" roto. Arq Bras Cardiol 1970; 23: 335-8.

52. Tostes Jr S, Meneses ACO, Corrêa-Araujo R, Lopes ER. Mecanismos pouco comuns de morte súbita no chagásico crônico - relato de três casos. Rev Soc Bras Med Trop 1989; 22: 97-8.

53. Tostes Jr S, Lopes ER, Chapadeiro E. Morte súbita por ruptura espontânea do ventrículo direito em mulher chagásica crônica - relato de caso. Rev Soc Bras Med Trop 1990; 23: 225-8.

54. Ramos SG, Matturri L, Rossi L, Rossi MA. Sudden cardiac death in the indeterminate phase of Chagas' disease associated with acute infarction of the right carotidy body. Int J Cardiol 1995; 52: 265-8.

55. Myerburg RJ, Kessler KM, Bassett AL, Castellanos A. A biological approach to sudden cardiac death: structure, function and cause. Am J Cardiol 1989; 63: 1512-6.

56. Junqueira Jr LF. Sobre o possível papel da disfunção autonômica cardíaca na morte súbita associada à doença de Chagas. Arq Bras Cardiol 1991; 56: 429-34.

57. Ramos SG, Matturri L, Rossi L, Rossi MA. Lesions of mediastinal paraganglia in chronic chagasic cardiomyopathy: cause of sudden death? Am Heart J 1996; 131: 417-20.

58. Baroldi G, Oliveira SJ, Silva MD. Sudden and unexpected death in clinically silent" Chagas'disease. A hypothesis. Int J Cardiol 1997; 58: 263-8.

59. Dias JCP, Kloetzel K. The prognostic value of the electrocardiographic features of chronic Chagas'disease. Rev Inst Med Trop São Paulo 1968; 10: 158-62.

60. Rassi A. Curva atuarial da taquicardia ventricular sustentada na cardiopatia chagásica crônica. In: Anais do IV Simpósio Brasileiro de Arritmias Cardíacas. Recife 1987: 129.

61. Carrasco HA. Factores pronosticos en la evolucion de la cardiopatia chagasica cronica. Rev Fed Arg Cardiol 1988; 17: 247-50.

62. Rassi SG, Rassi Jr A, Rassi AG, Lima AMC, Jatene JA, Rassi A. Avaliação da síncope e da pré-sincope na cardiopatia chagásica crônica através da estimulação elétrica programada. In: Anais do $2^{\circ}$ Congresso da Sociedade Latino-Americana de Estimulação Cardíaca. Porto Alegre, 1989: 36.

63. Rassi SG, Rassi Jr A, Jatene JA, Lima AMC, Ghannam VM, Rassi A. Significado clínico da indução de fibrilação ventricular, flutter ventricular e taquicardia ventricular polimórfica sustentados ao estudo eletrofisiológico. Arq Bras Cardiol 1991; 57(supl C): C2.

64. Rassi Jr A, Rassi AG, Rassi SG, Rassi Jr L, Rassi A. Relação entre sintomas, disfunção ventricular e arritmia ventricular na cardiopatia chagásica crônica. Arq Bras Cardiol 1992; 59(supl II): 182.

65. Scanavacca M, Sosa E. Estudo eletrofisiológico na cardiopatia chagásica crônica. Rev Soc Cardiol Estado São Paulo 1994: 2: 168-76.

66. Moraes AP, Moffa PJ, Sosa EA, et al. Eletrocardiograma de alta resolução na cardiopatia chagásica crônica. Rev Soc Cardiol Estado São Paulo 1994; 4: 177-82.

67. Martinelli Filho M, Sosa E, Nishioka S, Scanavacca M, Bellotti G, Pileggi F. Clinical and electrophysiologic features of syncope in chronic chagasic heart disease. J Cardiovasc Electrophysiol 1994; 5: 563-70.

68. Acquatella H, Guerra HC, Arribada A, et al. Estudios latinoamericanos. In: Storino R, Milei J, eds. Enfermedad de Chagas. Buenos Aires: Mosby 1994: 605-28.

69. Mady C, Cardoso RHA, Pereira-Barretto AC, Luz PL, Bellotti G, Pileggi F. Survival and predictors of survival in patients with congestive heart failure due to Chagas' cardiomyopathy. Circulation 1994; 90: 3098-102.

70. Bestetti RB, Dalbo CMR, Freitas OC, Teno LAC, Castilho OT, Oliveira JSM. Noninvasive predictors of mortality for patients with Chagas' heart disease: a multivariate stepwise logistic regression study. Cardiology 1994; 84: 261-7.

71. De Paola AAV, Gomes JA, Terzian AB, Miyamoto MH, Martinez EE. Ventricular tachycardia during exercise testing as a predictor of sudden death in patients with chronic chagasic cardiomyopathy and ventricular arrhythmias. Br Heart J 1995; 74: 293-5

72. Bestetti RB, Dalbo CM, Arruda CA, Correia Filho D, Freitas OC. Predictors of sudden cardiac death for patients with Chagas' disease: a hospital-derived cohort study. Cardiology 1996; 87: 481-7.

73. Pagani M, Lombardi F, Guzzetti S, et al. Power spectral analysis of heart rate and arterial pressure variabilities as a marker of sympathovagal interaction in man and conscious dog. Circ Res 1986; 59: 178-93.

74. Kleiger RE, Miller JP, Bigger JT, Moss AJ, and the Multicenter Post-Infarction
Research Group. Decreased heart rate variability and its association with increased mortality after acute myocardial infarction. Am J Cardiol 1987; 59: 256-62.

75. Zareba W, Moss AJ, leCessie S. Dispersion of ventricular repolarization and arrhythmic cardiac death in coronary artery disease. Am J Cardiol 1994; 74 : 550-3.

76. Koberle F. Cardiopatia chagásica. O Hospital 1958; 53: 9-50.

77. Guzzetti S, Iosa D, Pecis M, Bonura L, Prosdocimi M, Malliani A. Impaired heart rate variability in patients with chronic Chagas' disease. Am Heart J 1991; 121 1727-31.

78. Rassi A, Perini GE. Propafenona no tratamento da extra-sistolia ventricular da cardiopatia chagásica crônica. Estudo controlado através da eletrocardiografia dinâmica. Arq Bras Cardiol 1979; 32(supl 1): 46.

79. Porto CC, Guimarães E, Rosa J, Rassi A. Propafenona na prevenção das extra-sístoles ventriculares de etiologia chagásica relacionadas com o esforço físico. Avaliação por cicloergometria. Arq Bras Cardiol 1982; 39: 129-33.

80. Lorga AM, Greco OT, Garzon SAC, et al. Mexitil no tratamento de arritmias ventriculares de cardiopatas chagásicos crônicos. Rev Bras Med (Cardiologia) 1983; 1: 47-52.

81. Rassi A, Perini GE. Ensaio cego com disopiramida no tratamento da extra-sistolia ventricular da cardiopatia chagásica crônica controlado através do sistema Holter de eletrocardiografia dinâmica. Arq Bras Cardiol 1983; 41 (supl 1): 72.

82. Chiale PA, Halpern MS, Nau GJ, et al. Efficacy of amiodarone during long term treatment of malignant ventricular arrhythmias in patients with chronic chagasic myocarditis. Am Heart J 1984; 107: 656-65.

83. Carrasco HA, Vicuña AV, Molina C, et al. Effect of low doses of disopyramide and amiodarone on ventricular and atrial arrhythmias of chagasic patients with advanced myocardial damage. Int J Cardiol 1985; 9: 425-38.

84. Rassi Jr A, Rassi AG, Rassi SG, Rassi Jr L, Rassi A. Amiodarona no tratamento da extra-sistolia ventricular da cardiopatia chagásica crônica, com ajustes posológicos controlados através do Holter e do teste ergométrico. Arq Bras Cardiol 1991; 57(supl C): C8.

85. Rassi Jr A, Rassi AG, Rassi SG, Rassi A. Efeitos de doses crescentes de amiodarona sobre a supressão da arritmia ventricular ao Holter e ao teste ergométrico na cardiopatia chagásica crônica. Arq Bras Cardiol 1994; 63(supl I): 123.

86. Gizzi JC, Moreira DR, Sierra C,Zegarra-Carhvas R, Souza JE. Ação antiarrítmica do sotalol em cardiopatas com arritmia ventricular complexa. Arq Bras Cardiol 1994; 63(supl I): 71.

87. Rassi A, Rassi Jr A, Perini GE, Rassi AG, Rassi SG, Lorga AM. Eficácia de diferentes drogas antiarrítmicas na supressão da arritmia ventricular da Cardiopatia Chagásica Crônica. Análise através da eletrocardiografia dinâmica. Arq Bras Cardiol 1996; 67(supl I): 38

88. The Cardiac Arrhytmia Supression Trial (CAST) Investigators. Preliminary report: effect of encainide and flecainide on mortality in a randomized trial of arrhythmia supression after myocardial infarction. N Engl J Med 1989; 321: 406-12.

89. Echt DS, Liebson PR, Mitchell LB and the CAST Investigators. Mortality and morbidity in patients receiving encainide, flecainide, or placebo: the Cardiac Arrhythmia Suppression Trial. N Engl J Med 1991; 324: 781-8.

90. The Cardiac Arrhytmia Supression Trial II Investigators. Effect of the antiarrhythmic agent moricizine on survival after myocardial infarction. N Engl J Med 1992; 327: 227-33.

91. Burkart F, Pfisterer M, Kiowski W, Follath F, Buckhardt D. Effect of antiarrhythmic therapy on mortality in survivors of myocardial infarction with asymptomatic complex ventricular arrhythmias: Basel Antiarrhythmic Study of Infarct Survival (BASIS). J Am Coll Cardiol 1990; 16: 1711-8.

92. Ceremuzynski Y, KleczarE, Krzemirska-Pakula M, et al. Effect of amiodarone on mortality after myocardial infarction. J Am Coll Cardiol 1992; 20: 1056-62.

93. Navarro-Lopez F, Cosin J, Marrugat J, Guindo J, Bayes de Luna A, for the SSSD Investigators. Comparison of the effects of amiodarone versus metoprolol on the frequency of ventricular arrhythmias and on mortality after acute myocardial infarction. Am J Cardiol 1993; 72: 1243-8.

94. Doval HC, Nul DR, Grancelli HO, Perrone SV, Bortman GR, Curiel R for GESICA - Randomised trial of low dose amiodarone in severe congestive heart failure. Lancet 1994; 344: 493-8.

95. Garguichevich JJ, Ramos JL, Gambarte A, et al. Effect of amiodarone therapy on mortality in patients with left ventricular dysfunction and asymptomatic complex ventricular arrhythmias: Argentine pilot study of sudden death and Amiodarone (EPAMSA). Am Heart J 1995; 130: 494-500.

96. Cairns JA, Connolly SJ, Roberts R, Gent M, for the Canadian Amiodarone Myocardial Infarction Arrhythmia Trial Investigators. Randomised trial of outcome after myocardial infarction in patients with frequent or repetitive ventricular premature depolarisations: CAMIAT. Lancet 1997; 349: 675-82.

97. Sim I, McDonald KM, Lavori PW, Norbutas CM, Hlatky MA. Quantitative overview of randomized trials of amiodarone to prevent sudden cardiac death. Circulation 1997; 96: 2823-9. 
98. ATMA Investigators. Effect of prophylactic amiodarone on mortality after acute myocardial infarction and in congestive heart failure: meta-analysis of individual data from 6500 patients in randomised trials. Lancet 1997; 350: 1417-24.

99. Vorperian VR, Havighurst TC, Miller S, January CT. Adverse effects of low dose amiodarone: a meta-analysis. J Am Coll Cardiol 1997; 30: 791-8.

100. Sopher SM, Camm AJ. Adverse effects of amiodarone at low dose: plus Ça change. J Am Coll Cardiol 1997; 30: 799-801.

101. Hohnloser SH, Klingenheben T, Singh BN. Amiodarone-associated proarrhythmic effects: a review with special reference to Torsade de Pointes tachycardia. Ann Intern Med 1994; 121: 529-35.

102. Rassi A. Impacto do tratamento antiarrítmico e do uso do marcapasso na evolução do paciente chagásico. Trabalho apresentado durante o $51^{\circ}$ Congresso da Sociedade Brasileira de Cardiologia. Rio de Janeiro, 1995.

103. Scanavacca M, Sosa EA, Lee JH, Bellotti G, Pileggi F. Terapêutica empírica com amiodarona em portadores de miocardiopatia chagásica crônica e taquicardia ventricular sustentada. Arq Bras Cardiol 1990; 54: 367-71.

104. Gondim FAA, De Paola AAV, Silva RML, Mehta N, Martinez FºE. Eficácia e tolerância do sotalol em pacientes com taquiarritmias ventriculares sustentadas. Arq Bras Cardiol 1994; 62: 64.

105. Magalhães L, Sosa E, Marcial MB, et al. Resultados da crioablação endomiocárdica interpapilar no tratamento da taquicardia ventricular chagásica. Arq Bras Cardiol 1993; 61(supl II): II-18.

106. Takehara K, Scanavacca M, Sosa E, et al. Aspectos anátomo-patológicos do foco da taquicardia ventricular sustentada recorrente da miocardiopatia chagásica crônica. Arq Bras Cardiol 1990; 55(supl B): B68.

107. Sosa E, Scalabrini A, Rati M, Bellotti G, Pileggi F. Successful catheter ablation of the "origin" of recurrent ventricular tachycardia in chronic chagasic heart disease. J Electrophysiol 1987; 1: 58-61.

108. Rassi SG, Jatene JA,Sobrinho NA, et al. Ainda hálugar para a ablação transcateter com corrente elétrica direta no tratamento da taquicardia ventricular sustentada em cardiopatias? Reblampa 2000; 13(Supl I): 25.

109. Sosa E, Scanavacca M, D'Avila A, Pilleggi F. A new technique to perform epicardial mapping in the electrophysiology laboratory. J Cardiovas Electrophysiol 1996; 7: 531-6.

110. Sosa E, Scanavacca M, D'Avila A, et al. Endocardial and epicardial ablation guided by nonsurgical transthoracic epicardial mapping to treat recurrent ventricular tachycardia. J Cardiovasc Electrophysiol 1998; 9: 229-39.

111. Mirowski M, Reid PR, Mower MM, et al. Termination of malignant ventricular arrhythmias with an implanted defibrillator in human beings. N Engl J Med 1980; 303: 322-4

112. Bardy GH, Hofer B, Johnson G, et al. Implantable transvenous cardioverterdefibrillators. Circulation 1993; 87: 1152-68.

113. Sosa E, Marcial MB, Pileggi F. Taquicardia ventricular. Tratamento cirúrgico dirigido. Experiência inicial. Arq Bras Cardiol 1982; 38: 449-54.

114. Sosa EA, Scanavacca M, Marcial MB, Jatene A. Terapêutica não farmacológica das arritmias. In: Barretto ACP, Souza AGMR, eds. SOCESP Cardiologia. Atualização e reciclagem. $1^{\text {a }}$ ed. Rio de Janeiro: Atheneu 1994: 699-712. 